\title{
Cuticles of Paripteris Gothan, 1941 (Pteridospermopsida) from the Westphalian of Poland
}

\author{
ZBYNĚK ŠIMŮNEK
}

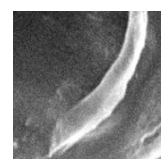

\begin{abstract}
Leaf cuticles of two Carboniferous trigonocarpalean "medullosan" pteridosperms of the genus Paripteris Gothan are described. P. gigantea (Sternberg) Gothan and P. linguaefolia (Bertrand) Laveine have strikingly similar cuticles. The adaxial cuticles have elongated tetragonal cells orientated parallel to the veins. The cells of the abaxial cuticle are probably polygonal with only faintly discernible anticlinal walls. The haplocheilic stomata are deeply sunken in the case of $P$. linguaefolia as revealed under SEM. Putative proximal papillae seen light-microscopically appear to be structures encased by sunken stomata. The differences between $P$. gigantea and $P$. linguaefolia are restricted to the presence of trichomes respectively trichome bases and differences in stomatal density values. There are two concepts of the intrageneric classification of Paripteris. In contrast to the widely used traditional binomial classification, Zhang et al. (1993) preferred to provisionally interpret all the so far described species assigned to Paripteris as formae of $P$. gigantea. The new information on cuticular structures neither confirms, nor fully disproves either one of the above-mentioned classifications. - Key words: Paripteris, cuticular analysis, Westphalian.
\end{abstract}

ŠIMŮNEK, Z. 2010. Cuticles of Paripteris Gothan, 1941 (Pteridospermopsida) from the Westphalian of Poland. Bulletin of Geosciences 85(2), 353-360 (6 figures, 2 tables). Czech Geological Survey, Prague. ISSN 1214-1119. Manuscript received March 22, 2010; accepted in revised form April 30, 2010; published online June 8, 2010; issued June 30, 2010.

Zbyněk Šimůnek, Czech Geological Survey, Klárov 131/3, 11821 Praha 1, Czech Republic; zbynek.simunek@ geology.cz

The genus Paripteris Gothan, 1941 is very well known thanks to the work of J.-P. Laveine. Since his first comprehensive description (Laveine 1967), he studied the distribution and migration of this genus from Asia to Europe and North America (Laveine et al. 1993, 2003; Zhang et al. 1993) and published a reconstruction of the plant and its frond and deciphered its frond architecture as "pseudopinnate" (Laveine et al. 1993, Laveine 1997). Fronds disintegrated very rapidly, loosing their pinnules after they broke off the plant, which explains the quantity of isolated pinnules often found on bedding surfaces. His studies in China (Laveine et al. 1993, 2003) resulted in a new classification of Paripteris. He studied localities of Viséan and Namurian age and found an assemblage of isolated paripterid pinnules exhibiting great variability. Zhang et al. (1993) detected four to five Paripteris "species" in the same locality and argued that it is not tenable to have so many closely related species on the same bedding surface. Moreover, Laveine et al. (1993) also found a large frond with pinnules that could be assigned to at least three different Paripteris species. Therefore, they reclassified the species of the genus Paripteris. Only $P$. gigantea, the genus type, was retained; the other species were regarded as formae of $P$. gigantea. Not all palaeobotanists accepted this classification, e.g. Cleal \& Shute (1995), Migier in Brzyski et al. (2001) and Cleal (2008) and others. Laveine et al.'s (1993) classi- fication fits better to Asian than to European representatives of Paripteris. European representatives of Paripteris do not show such great variability as seen in the Asian ones. For instance, Paripteris (P. gigantea f. acuminatissima) acute pinnules do not occur in Europe, whereas they are common in Asia. In Europe, in the Chockerian and Yeadonian, only $P$. gigantea occurs. This species is widespread in the Langsettian. However, $P$. pseudogigantea and $P$. linguaefolia first appear at the end of the Langsettian. These "species" or "forms" became more dominant in the Duckmantian and Bolsovian, where $P$. linguaefolia is an index species for the P. linguaefolia Zone (Wagner 1984). $P$. gigantea is locally still common in the Duckmantian and becomes very rare in the Bolsovian and then rapidly disappeared. P. linguaefolia is common throughout the Bolsovian and had its last occurrence at the end of the Bolsovian. Even though these species sometimes occur in the same localities, it is difficult to explain the very long stratigraphic occurrence of $P$. gigantea and relatively short occurrence of $P$. pseudogigantea and $P$. linguaefolia. The stratigraphic ranges of these "species" overlap only in the Duckmantian and in part of the Bolsovian (Table 1).

In this paper the problem as to whether $P$. linguaefolia and $P$. pseudogigantea are true species, or only forms of $P$. gigantea is addressed by means of cuticular analysis. Barthel (1961) was the first author who studied the cuticles 


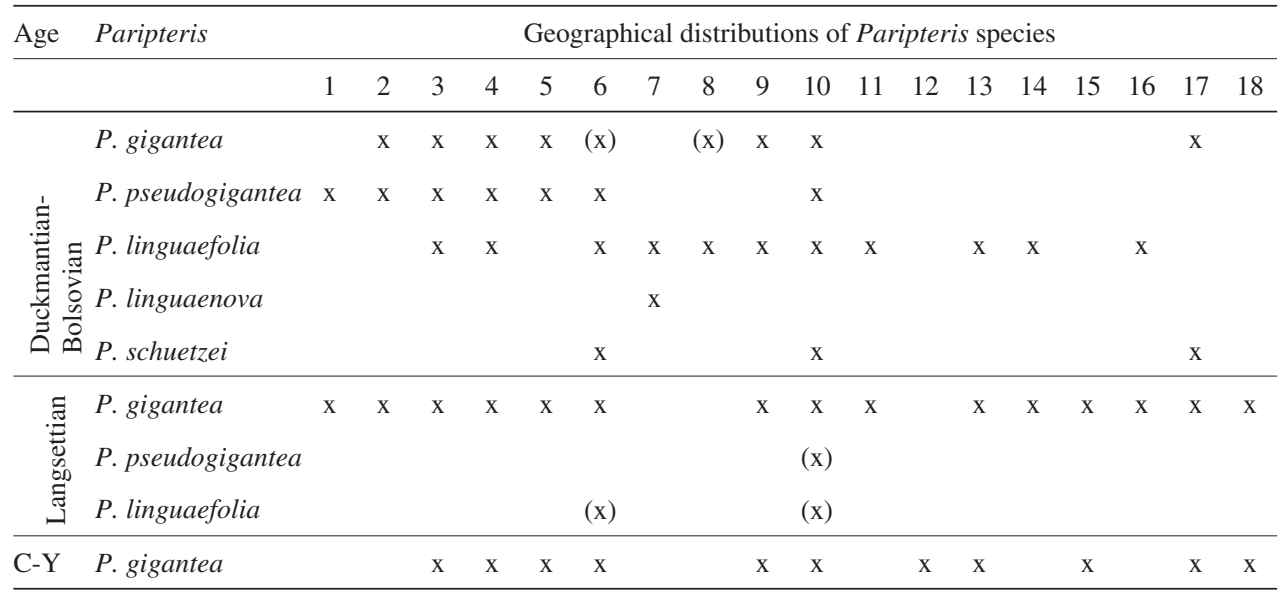

Table 1. Geographical and stratigraphical distribution of European species of Paripteris. $\mathrm{x}$ - presence in the interval according to Cleal \& Shute (1995), Polish data corrected according to Brzyski et al. (2001), (x) - very rare and usually at the base or top of the interval, C-Y - Chokierian-Yeadonian. 1: S-W United Kingdom, 2: Pennines, 3: Franco-Belgian Basin, 4: NW Germany, 5: NE Germany, 6: Lublin, 7: Saar-Lorraine, 8: Central Bohemia, 9: Intrasudetic, 10: Upper Silesia, 11: Alps, 12: Pyrenees, 13: NW Spain, 14: S. Spain, 15: Svoge, 16: Turkey, 17: Donets, 18: N. Caucasus.
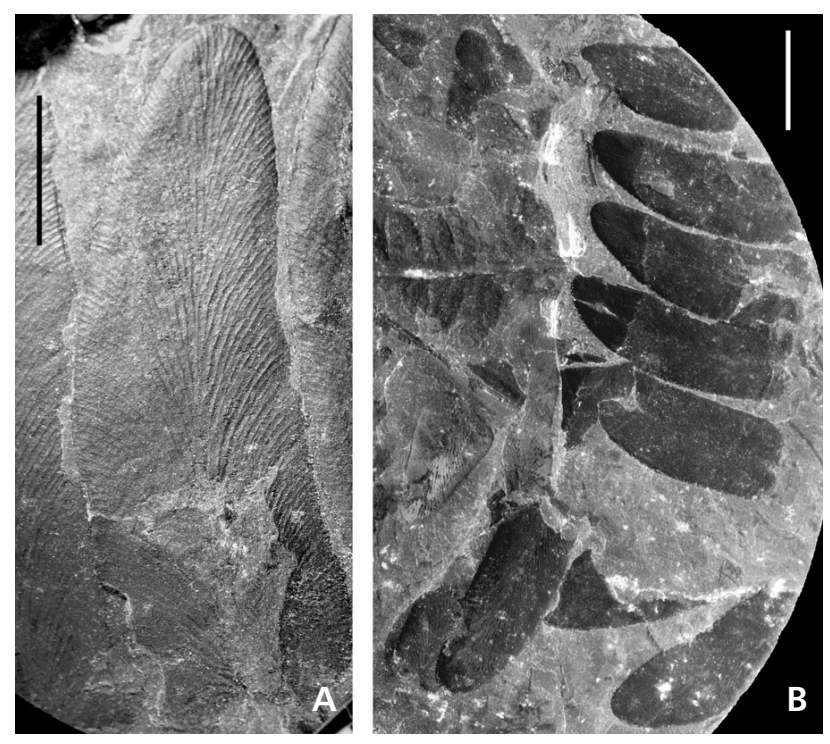

Figure 1. Paripteris gigantea (Sternbrg) Gothan, borehole Jastrzębie 25, depth $371.5 \mathrm{~m}$, Załeż Member, Langsettian. • A - detail of a pinnule, scale bar $=5 \mathrm{~mm}$. $\bullet \mathrm{B}-$ part of the ultimate pinna, scale bar $=1 \mathrm{~cm}$.

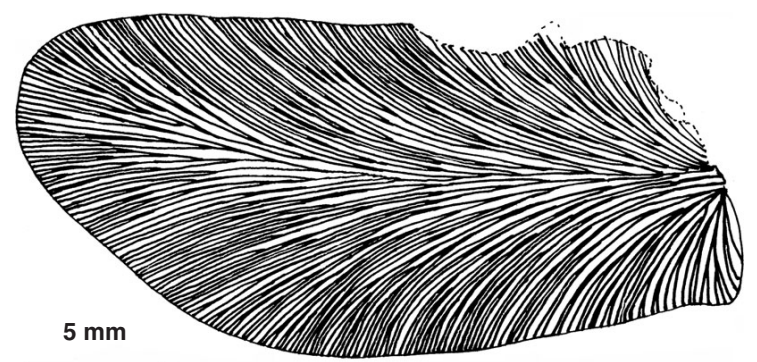

A

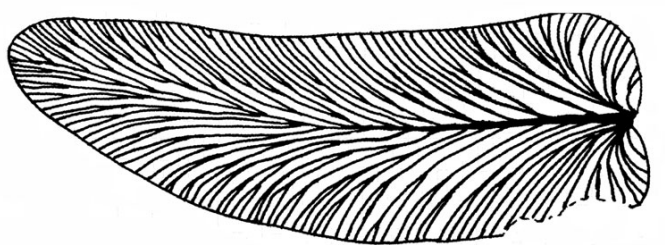

B

Figure 2. Venation form of $P$. linguaefolia (A, see Fig. 4B) and P. gigantea (B, see Fig. 1A). of $P$. gigantea from the Langsettian of the Upper Silesian Basin, Poland. The abaxial cuticles show papillate stomatal complexes orientated parallel to the veins; the adaxial cuticle has oblong to longitudinal polygonal cells also orientated in one direction. Šimůnek (2007) published a figure of abaxial cuticle belonging to $P$. linguaefolia with strongly papillate stomatal complexes from the Bolsovian of the Kladno-Rakovník Basin (Czech Republic). Cuticles of $P$. gigantea from the Duckmantian of the Intrasudetic Basin (Czech Republic) were reinvestigated by Šimůnek (2009). The present paper deals with cuticles of the $P$. linguaefolia and $P$. gigantea from the Upper Silesian Basin (Poland). The cuticles of $P$. linguaefolia are very well preserved and reveal important new information, particularly when studied using scanning electron microscopy.

\section{Systematic palaeobotany}

Material and methods. - The macerated specimens are stored in the Polish Geological Institute, Upper Silesian Branch in Sosnowiec, Poland. They are from Teresa Migier's collection from the Upper Silesian Basin and the collection numbers are $4 P$. gigantea (originally identified as $P$. pseudogigantea, borehole Jastrzębie 25, depth 371.5 m, Załeż Member, Langsettian, Westphalian A) and 472/239 P. linguaefolia (Suszec, borehole IG 9, depth 813.5 m, Orzesze Member, Duckmantian, Westphalian B). The method of cuticle preparation is that used by Šimůnek (2009, p. 120).

Class Pteridospermopsida

Order Medullosales (Trigonocarpales)

\section{Genus Paripteris Gothan, 1941}

Type species. - Paripteris gigantea (Sternberg, 1821) Gothan, 1941. 

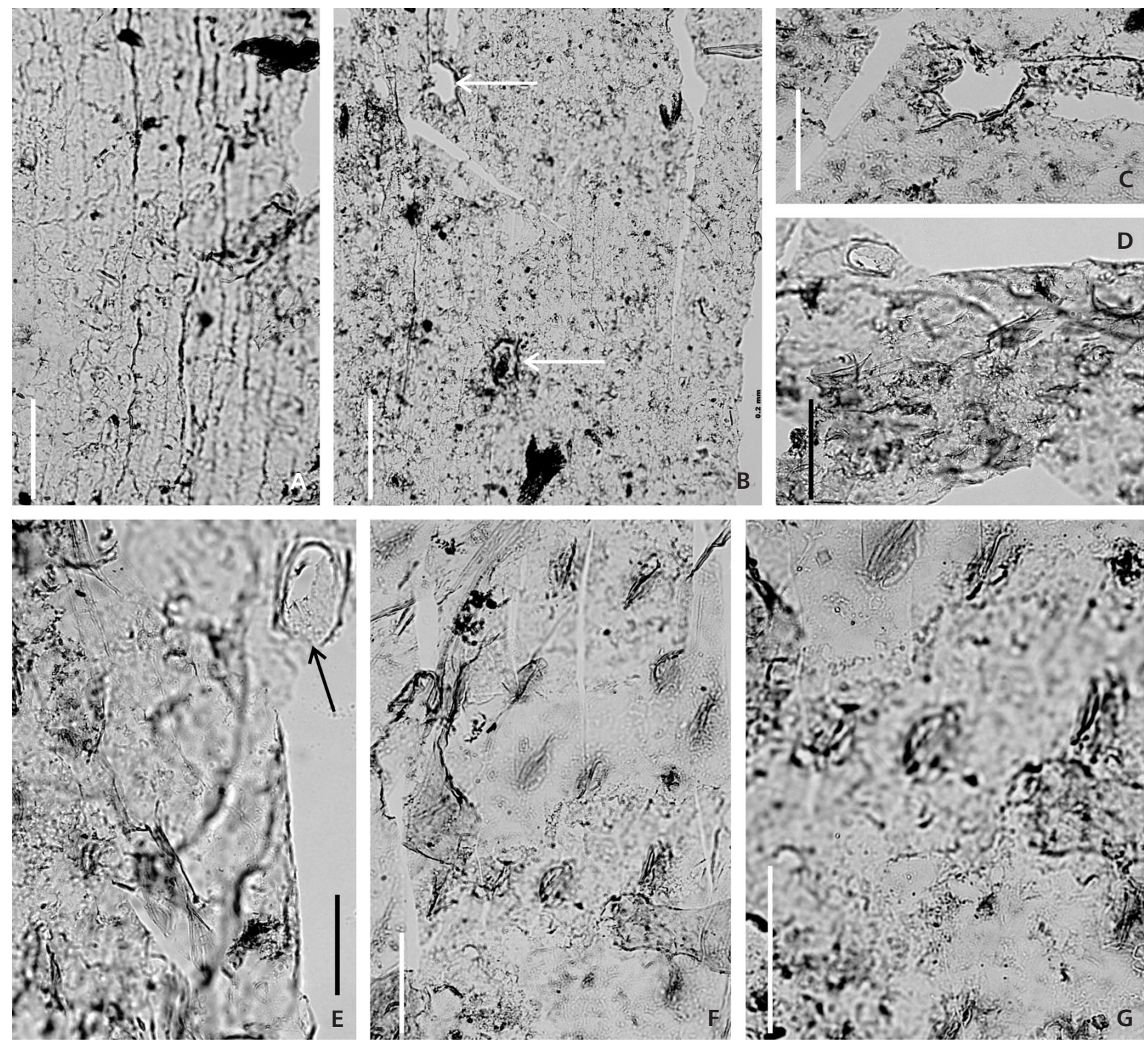

Figure 3. Cuticles of Paripteris gigantea (Sternberg) Gothan from Fig. 1. $\bullet$ A - adaxial cuticle, slide $515 / 1$, scale bar $=50 \mu \mathrm{m}$. B - adaxial side probably in the area of the midrib with two structural holes (trichome bases, arrows), slide 515/1, scale bar $=100 \mu \mathrm{m}$. $\bullet \mathrm{C}-$ detail of a structural hole from Fig. 3B, scale bar $=50 \mu \mathrm{m}$. $\cdot \mathrm{D}-$ a fragment of abaxial cuticle with stomata in the intercostal field and a structural hole (trichome base, arrow) in the costal field, slide $515 / 5$, scale bar $=100 \mu \mathrm{m}$. $\bullet \mathrm{E}$ - detail of stomata and a structural hole from Fig. 3D, scale bar $=50 \mu \mathrm{m} . \bullet \mathrm{F}-$ stomata in the intercostal field, slide $515 / 6$, scale bar $=50 \mu \mathrm{m} . \bullet \mathrm{G}-$ detail of stomata from Fig. $3 \mathrm{~F}$, scale bar $=50 \mu \mathrm{m}$.

\section{Paripteris gigantea (Sternberg, 1821) Gothan, 1941} Figures 1, 2B, 3

For comprehensive synonymy see Šimůnek (2009) and Laveine (1967).

Description of the hand specimen. - Five pinnules are preserved on the left side of the ultimate pinna (Fig. 1B). The pinnules are tongue-shaped, slightly falcate with a cordate base and blunt apex. The pinnules are 22-24 $\mathrm{mm}$ long and $7-8 \mathrm{~mm}$ wide. The venation density is $25-30$ veins per
$1 \mathrm{~cm}$ on the pinnule margin. The midvein is prominent up to around half the pinnule length (Fig. 2B). The lateral veins arise obliquely from the midvein, divide up to three times and reach the pinnule margin at an angle of 50 to $65^{\circ}$.

Description of cuticles (slides 415/1-6). - Pinnule adaxial cuticle (Fig. 3A): Costal and intercostal fields can not be clearly differentiated. Anticlinal cell walls are thinly cutinised and difficult to observe (Fig. 3A); they are longitudinally tetragonal (oblong or trapezoidal), 40-100 $\mu \mathrm{m}$ long and $8-16 \mu \mathrm{m}$ wide. 

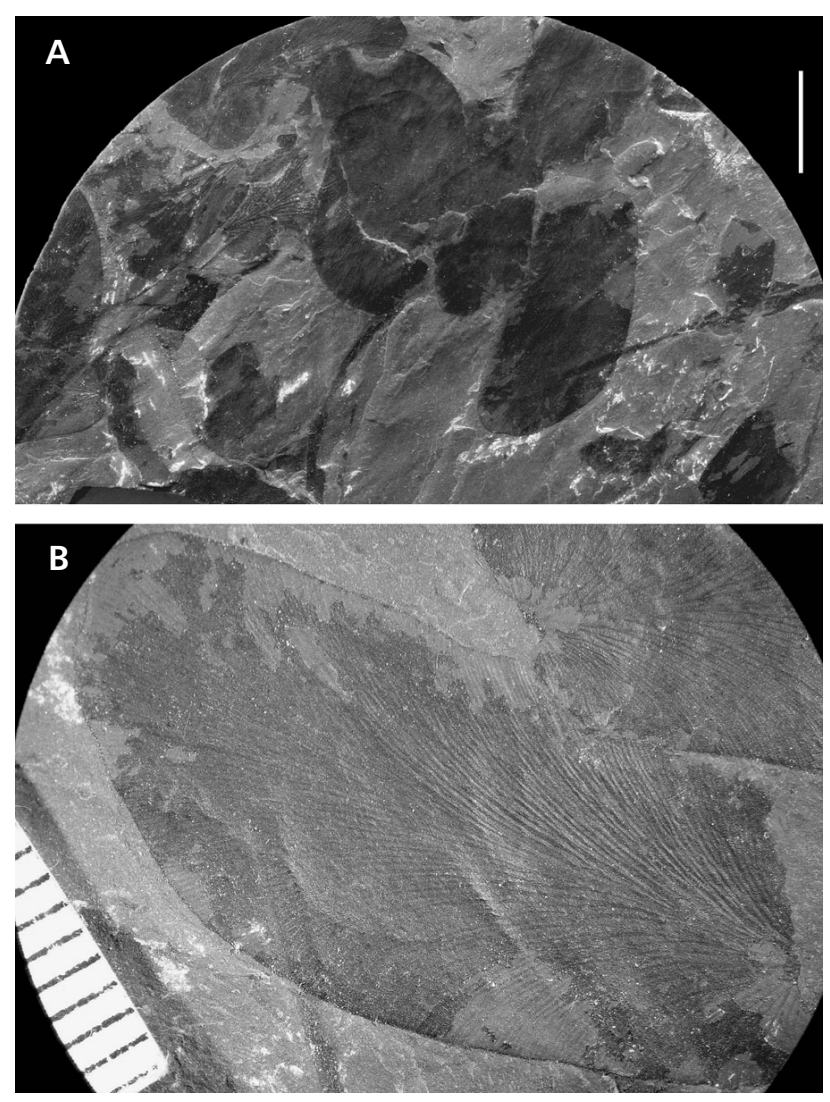

Figure 4. Paripteris linguaefolia (Bertrand) Laveine, loc. Suszec, borehole IG 9, depth 813.5 m, Orzesze Member, Duckmantian. • A - a few isolated pinnules, scale bar $=1 \mathrm{~cm}$. $\bullet \mathrm{B}$ - detail of a pinnule, scale bar in $\mathrm{mm}$.

Pinnule abaxial cuticle (Fig. 3B-G): The anticlinal walls are also very thinly cutinised and cell outlines are difficult to trace. The costal and intercostal fields differ in the presence of stomata in the intercostal fields and trichome bases in the costal fields. The intercostal cells are polygonal, mostly elongated, clearly visible only in part of the cuticle; they are 20-30 $\mu \mathrm{m}$ long and up to $20 \mu \mathrm{m}$ wide. Monocyclic, deeply sunken stomata, 23-30 $\mu \mathrm{m}$ long and $10-14 \mu \mathrm{m}$ wide, are orientated parallel to veins; 5 to 6 elongated polygonal to trapezoidal subsidiary cells surround each stoma. The stomatal density is approximately 260 stomata per $\mathrm{mm}^{2}$. The stomatal index could not be determined. The cells of the costal fields are similar to those on the adaxial cuticle but smaller. Oval pore-like structures representing trichome bases (Fig. 3D, E), 45-50 $\mu \mathrm{m}$ long and 25-30 $\mu \mathrm{m}$ wide, occur rarely among these cells.

Cuticle of the midrib (Fig. 3B, C): This cuticle with elongated tetragonal cells is too wide for costal fields, it probably represents the abaxial cuticle of the midrib. Oval to elliptical pores, 45-50 $\mu \mathrm{m}$ long and 25-30 $\mu \mathrm{m}$ wide, with more strongly cutinised, mostly irregular outlines, as in papillae, are present, probably they are trichome bases (Fig. 3C). Only small pinnule fragments were macerated; therefore the results are not as good as in the case of the Žaclér specimen (Šimůnek 2009).
Paripteris linguaefolia (Bertrand, 1930) Laveine, 1967 Figures 2A, 4-6

For comprehensive synonymy see Laveine (1967).

Description of the hand-specimen. - Only isolated pinnules in a slab (Fig. 4) are preserved. The pinnules are large, broadly lingulate, with a faintly cordate base and round apex. The pinnules are 26-28 mm long and 10-12 mm wide. The pedicel is positioned asymmetrically. Either there is no midrib or only a very short midrib. Lateral veins maybe diverging in a fan-shaped manner from the pedicel or arising at a very sharp angle from the short midrib; the midrib consists of very narrowly spaced lateral veins (Fig. 2A). The lateral veins run in a slightly oblique direction through the blade, divide 3 to 7 times and reach the pinnule margin at angles of $55-70^{\circ}$. The venation density is 42 to 50 veins per $1 \mathrm{~cm}$ on the pinnule margin.

Description of the cuticles. - The cuticles are very well preserved thus enabling light and scanning electron microscopic studies.

Pinnule adaxial cuticle (Figs 5A, B, D, 6E, H): Costal and intercostal fields can not be clearly differentiated. Anticlinal cell walls are thinly cutinised, as can be seen in the SEM pictures (Fig 6E, H). The cells are longitudinally tetragonal (oblong or trapezoidal), 50-130 $\mu \mathrm{m}$ long and 10-20 $\mu \mathrm{m}$ wide.

Pinnule abaxial cuticle (Figs 5C-I, 6A-D, F, G, I, J): Costal and intercostal fields are clearly distinguishable. Costal cells are usually oblong to trapezoidal, 40-70 $\mu \mathrm{m}$ long and 8-12 $\mu \mathrm{m}$ wide. Rounded to oval pores, representing trichome bases, are present; unicellular bent trichomes have been observed (Fig. 5F, G). These trichomes are 125-150 $\mu \mathrm{m}$ long and 30-40 $\mu \mathrm{m}$ wide and widen towards their base, which is $80-90 \mu \mathrm{m}$ in diameter. Two types of trichome bases occur; one type is broadly oval $45-55 \mu \mathrm{m}$ long and 30-40 $\mu \mathrm{m}$ wide, whereas the other is narrowly oval 90-120 $\mu \mathrm{m}$ long and $30-35 \mu \mathrm{m}$ wide. It is interesting to note that half of the margin around these pores is more strongly cutinized, whereas the other half of the margin shows the same cutinization as the rest of the cuticle (Figs 5H, 6A, B).

The intercostal cells are poorly discernible, only prominent stomata are clearly visible (Fig. 5C). Under SEM (Fig. 6A, I), the monocyclic stomata, deeply sunken $(15-20 \mu \mathrm{m})$ below the epidermis level are clearly observable. The guard cells are elliptical, 22-34 $\mu \mathrm{m}$ long and 9-14 $\mu \mathrm{m}$ wide. The stomatal slit is usually $20-25 \mu \mathrm{m}$ long (Fig. 6D). The stomatal density is 320-370 stomata per $\mathrm{mm}^{2}$. The stomatal index is difficult to determine. The anticlinal walls of the ordinary cells are very weakly cutinized as can be seen under SEM (Fig. 6I). The cells are usually elongated, polygonal, 24-34 $\mu \mathrm{m}$ long and $10-15 \mu \mathrm{m}$ wide. The outer surface of the cuticle is not 

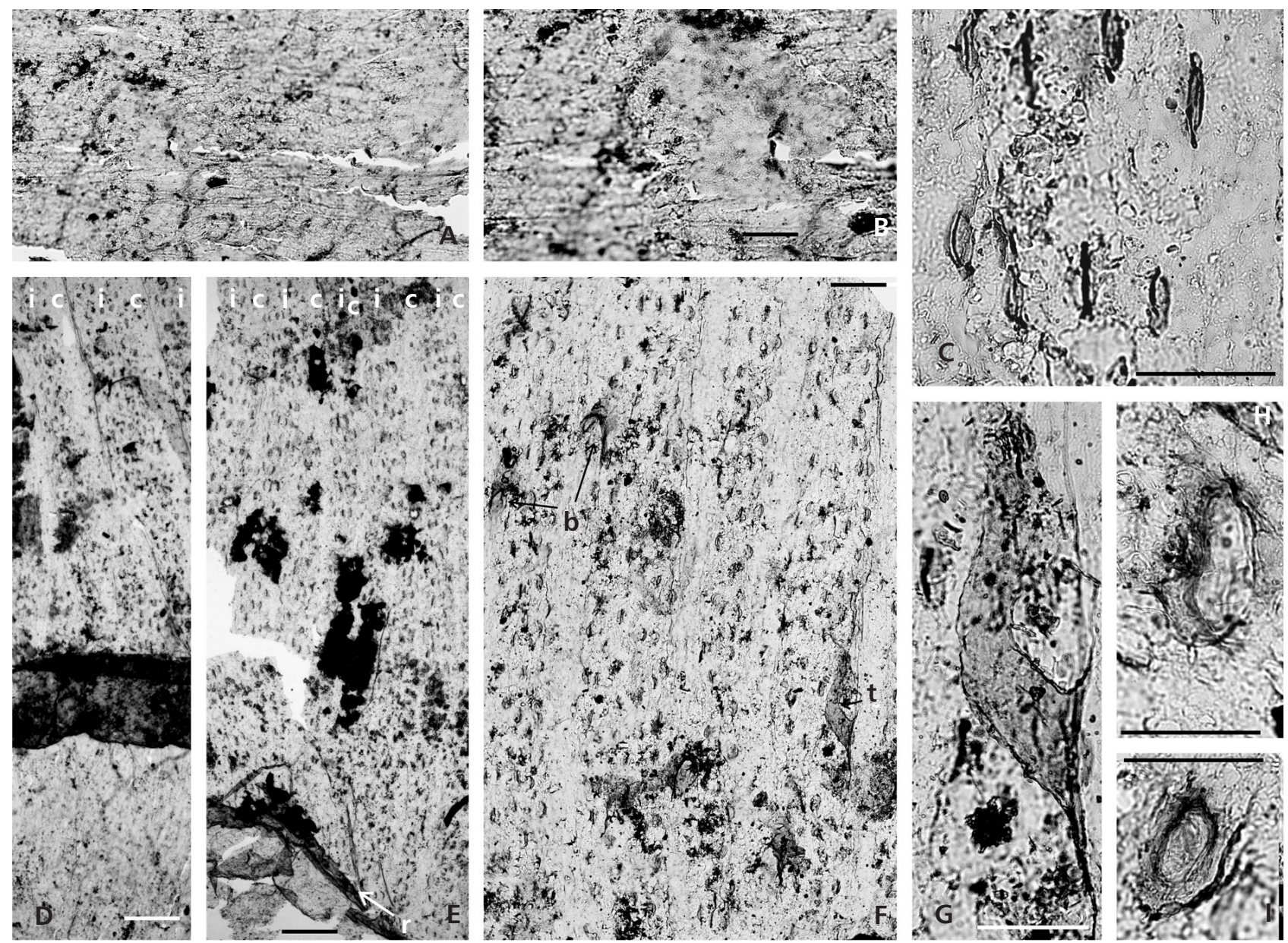

Figure 5. Cuticles of Paripteris linguaefolia (Bertrand) Laveine. $\bullet$ A - adaxial cuticle from Fig. 5D, scale bar $=100 \mu$ m. $\bullet$ B - detail from Fig. 5A, scale bar $=50 \mu \mathrm{m} . \bullet \mathrm{C}-$ abaxial cuticle with stomata in the intercostal field from Fig. $5 \mathrm{~F}$, costal field is above and below, scale bar $=50 \mu \mathrm{m}$. $\bullet \mathrm{D}-$ adaxial cuticle (below) and abaxial cuticle (above), i - intercostal fields with stomata, c - costal fields, slide 514/7, scale bar $=200 \mu \mathrm{m}$. $\bullet$ E - adaxial cuticle on the lower left corner and abaxial cuticle, $\mathrm{r}$ - rim between adaxial and abaxial cuticle, $\mathrm{i}$ - intercostal fields with stomata, c - costal fields, slide 514/5, scale bar $=200 \mu \mathrm{m}$. $\bullet \mathrm{F}-$ abaxial cuticle with costal and intercostal fields, $\mathrm{b}-$ trichome bases, $\mathrm{t}-$ trichome, scale bar $=100 \mu \mathrm{m}$. $\bullet \mathrm{G}-\mathrm{detail}$ of a trichome from Fig. 5F, scale bar $=50 \mu \mathrm{m}$. $\bullet \mathrm{H}, \mathrm{I}-$ trichome bases from the costal field, $\mathrm{H}-$ slide $514 / 3$, I - slide $514 / 7$, scale bar $=50 \mu \mathrm{m}$.

smooth, but seems to be covered by tiny scales. Only closed stomatal pores were observed (Fig. 6D).

Cuticle of the pinnule rim (Fig. 5D, E): The rim between the adaxial and abaxial cuticle is strongly cutinised and 50-60 $\mu \mathrm{m}$ wide; trichome bases are absent.

\section{Comparison of Paripteris species}

$P$. linguaefolia differs from $P$. gigantea, $P$. pseudogigantea and $P$. schuetzei by the absence of a (markedly longer) midrib but presence of fan-shaped venation. $P$. schuetzei and $P$. pseudogigantea usually have smaller pinnules, a prominent, coarser venation, and often a vaulted pinnule blade. The midrib is always very distinct, in length up to $4 / 5$ of the pinnule length. $P$. gigantea has a prominent midrib in length at least $1 / 2$ of the pinnule length. $P$. gigantea and $P$. linguaefolia usually have relatively large pinnules. The venation density does not appear significant for distinguishing individual species. The venation density can vary greatly between different specimens of the same species (Table 2).

Taken together available data, the adaxial cuticle of $P$. gigantea is very similar to $P$. linguaefolia. The cells are elongate tetragonal. The adaxial cuticles of $P$. gigantea figured by Barthel (1961) differ from the adaxial cuticles figured by Šimůnek (2009) and those illustrated here in having much wider cells. Barthel (1961) figured a very small fragment and it is difficult to say whether it is part of the abaxial or adaxial side of a midrib; it is definitely not typical adaxial cuticle. Abaxial cuticles of $P$. linguaefolia and $P$. gigantea are very similar in the specimens illustrated by Barthel (1961) and Šimůnek (2009, this paper). The stomata in the specimens studied by the present author are approximately 22-30 $\mu \mathrm{m}$ long, whereas they are only 15-20 $\mu \mathrm{m}$ long in the material studied by Barthel (1961). However, his illustrations show that they are 20-26 $\mu \mathrm{m}$ 
Table 2. Some morphological and micromorphological features of the species Paripteris gigantea and Paripteris linguaefolia. Explanation: USB - Upper Silesian Basin, ISB - Intrasudetic Basin, West. - Westphalian, * - cuticle of midvein, ** - from Barthel (1961, pl. 4, fig. 1).

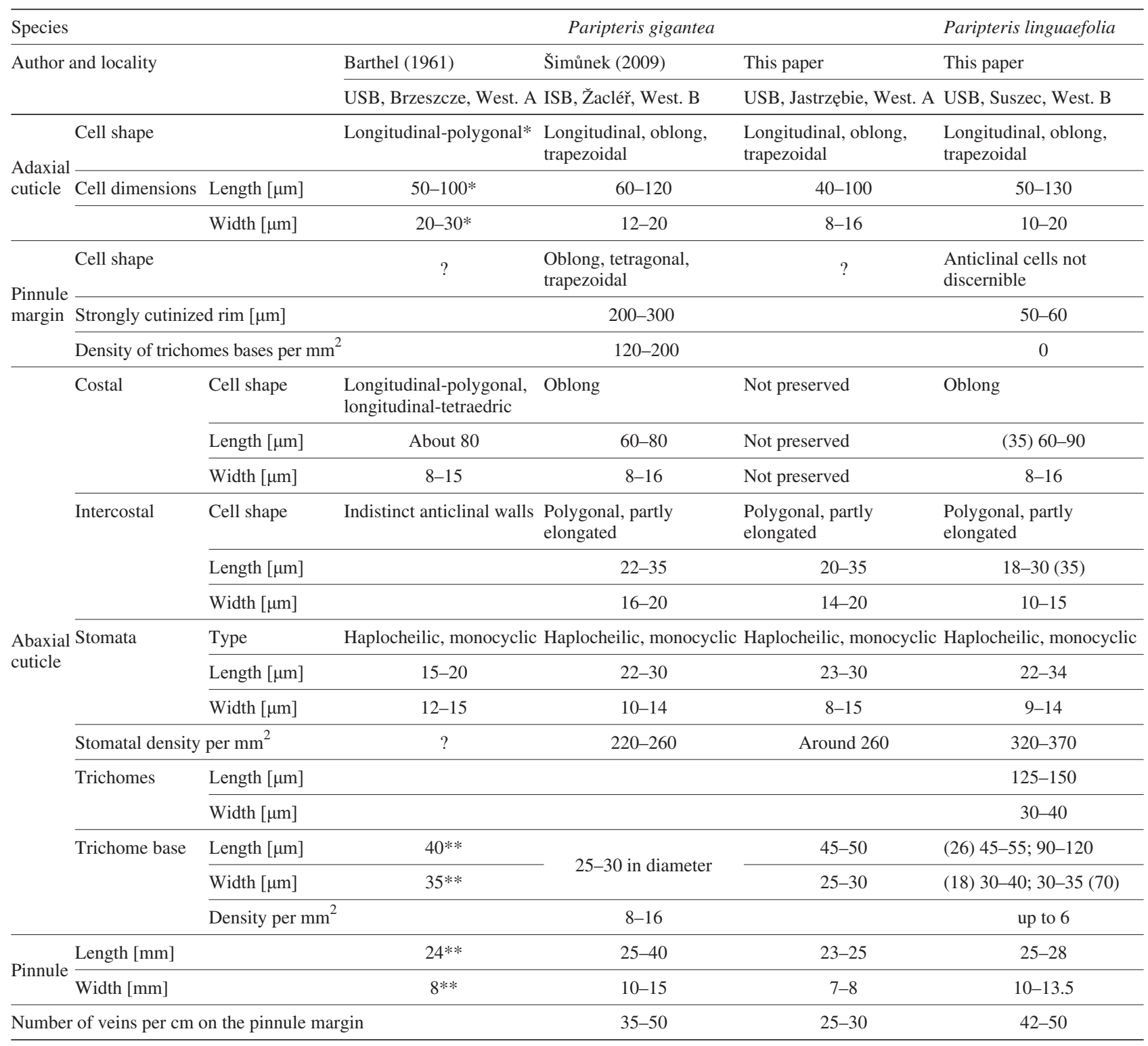

long. Barthel (1961) mentioned the occurrence of proximal papillae on some subsidiary cells. Papillae also seemed to be present in the cuticles figured by Šimůnek (2009). However, observations under the scanning electron microscope revealed the true nature of this feature in $P$. linguaefolia (Fig. 6). The guard cells are deeply sunken and when the stomatal slit is closed, it looks as if proximal papillae, partly covering the guard cells, are developed (Fig. 5I). The small, 45-50 $\mu \mathrm{m}$ long and 25-30 $\mu \mathrm{m}$ wide, oval trichome bases in the costal field appear to be typical for all samples. Narrow, elongated oval trichome bases, 90-120 $\mu \mathrm{m}$ long, are only present in the costal fields of $P$. linguaefolia also the 125-150 $\mu \mathrm{m}$ long unicellular bent trichomes. This feature distinguishes $P$. linguaefolia from $P$. gigantea. The other difference is the pinnule margin. The pinnule margin of P. gigantea (Šimůnek 2009) is formed by a 200-300 $\mu \mathrm{m}$ wide zone of specialised cells with numerous trichome bases. $P$. linguaefolia has only a 50-60 $\mu \mathrm{m}$ wide zone of more cutinized cells without trichome bases. Trichomes have not yet been observed in $P$. gigantea.

The stomatal density in the two species also differs. $P$. gigantea has a stomatal density of 220-260 stomata per $\mathrm{mm}^{2}$, whereas $P$. linguaefolia has a stomatal density of 320-370 stomata per $\mathrm{mm}^{2}$. These differences may be caused by differences in environmental and palaeoatmospheric parameters, e.g. different $\mathrm{CO}_{2}$ concentrations, but this needs to be tested by studying more samples from different stratigraphical levels. 

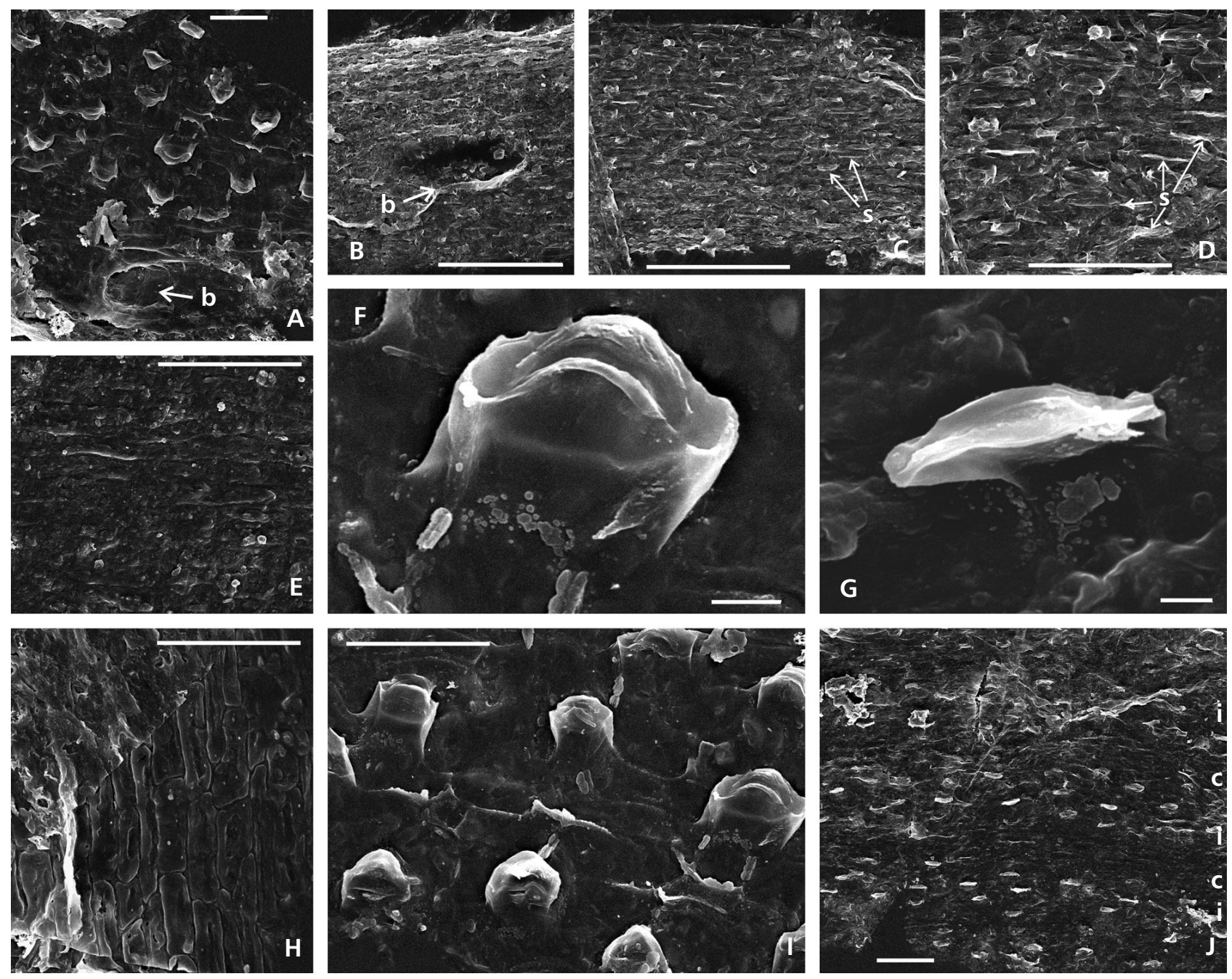

Figure 6. Cuticles of Paripteris linguaefolia (Bertrand) Laveine in SEM, stump No. 54. • A - abaxial cuticle from an internal view with stomata and a trichome base (b), scale bar $=50 \mu \mathrm{m}$. $\bullet \mathrm{B}-$ abaxial cuticle from the outer side with a trichome base (b), scale bar $=100 \mu \mathrm{m}$. $\bullet \mathrm{C}-$ abaxial cuticle from the outer side with stomata (s), scale bar $=100 \mu \mathrm{m}$. $\bullet \mathrm{D}-$ detail from Fig. $6 \mathrm{C}$ with stomata (s), scale bar $=50 \mu \mathrm{m}$. $\bullet \mathrm{E}-$ adaxial cuticle from an external view, scale bar $=100 \mu \mathrm{m} . \bullet \mathrm{F}$ - detail of a stoma from Fig. $6 \mathrm{I}$, scale bar $=10 \mu \mathrm{m} . \bullet \mathrm{G}-$ detail of a stoma from Fig. $6 \mathrm{~J}$, scale bar $=10 \mu \mathrm{m}$. $\bullet \mathrm{H}-$ adaxial cuticle from an internal view, scale bar $=50 \mu \mathrm{m}$. $\bullet \mathrm{I}-$ detail from Fig. $6 \mathrm{~A}$, scale bar $=50 \mu \mathrm{m} . \bullet \mathrm{J}-$ abaxial cuticle from the inner side with costal fields (c) and intercostal fields with stomata (i), scale bar $=100 \mu \mathrm{m}$.

\section{Discussion}

The basic question is: is $P$. linguaefolia an independent species or just a form of $P$. gigantea? This question is difficult to answer. The cuticles of above-mentioned species are very similar. They differ only in the pinnule rim and in the presence of trichomes in $P$. linguaefolia. New macerations will be necessary in order to verify how significant the pinnule rim is for distinguishing between $P$. gigantea and $P$. linguaefolia. In other words, whether the rim is a stable diagnostic feature or not, and whether trichomes also occur in $P$. gigantea. Nowadays, it is impossible to resolve this problem based on only cuticle structure.

If we look at the genus Laveineopteris, we can see that the species of this genus also have very similar cuticles, e.g., L. loshii and L. tenuifolia. But these species differ in cell size, in the presence of small trichome bases near the midvein of L. tenuifolia (Cleal \& Zodrow 1989), and in stomatal density. According to Cleal \& Zodrow (1989) L. loshii has 200 stomata per $\mathrm{mm}^{2}$ of pinnule blade, whereas L. tenuifolia has 300 stomata per $\mathrm{mm}^{2}$ of pinnule blade. Cleal \& Shute (1992) stated that L. loshii has a stomatal density of 325 stomata per $\mathrm{mm}^{2}$ of pinnule blade. It thus seems that stomatal density is not significant in this particular species. It depends on the $\mathrm{CO}_{2}$ concentration in the atmosphere which changed with time. Cleal et al. (1999) demonstrated changes in stomatal density of Neuropteris ovata over time.

In recent literature, the binomial classification of Paripteris is still commonly used, e.g., Migier in Brzyski et 
al. (2001) and Cleal (2008). Therefore, I also use this classification here. Cuticular data from the two species of Paripteris do not support the "trinominal" classification proposed by Zhang et al. (1993), but it cannot be rejected either. It will be necessary to prepare cuticles from further material to answer this question.

\section{Conclusion}

Cuticular studies of $P$. gigantea and $P$. linguaefolia have not solved the classification problem regarding the taxa assignable to Paripteris, i.e. whether these taxa should be retained as separate taxa, or whether $P$. linguaefolia and other species traditionally assigned to Paripteris should be regarded as synonyms of $P$. gigantea, having the status of formae as was advocated by Zhang et al. (1993). The cuticles of $P$. gigantea and $P$. linguaefolia are very similar, but there are some differences. The main differences are the presence of trichome bases on pinnule margins of $P$. gigantea and presence of trichomes in $P$. linguaefolia cuticles ( $P$. gigantea has only trichome bases). The two species have different stomatal densities. The degree of variability in these features within individual species is not known. It will therefore be necessary to verify cuticular variability of in more specimens before the problem can finally be solved.

\section{Acknowledgements}

This research was conducted with support of the Grant Agency of the Czech Republic (205/05/2034, P210/10/0232) and Research Aim of the Czech Geological Survey (MZP0002579801). A. Zdanowski, A. Trzepierczynska, A. Kotasowa and T. Migier (Geological Institute in Sosnowiec, Poland) are acknowledged for their assistance in the study of the Sosnowiec collection.

\section{References}

BARTHEL, M. 1961. Der Epidermisbau einiger oberkarbonischer Pteridospermen. Geologie 10, 828-849.

BERTRAND, P. 1930. Bassin Houiller de la Sarre et de la Lorraine. I. Flore Fossile. $1^{\text {er }}$ Fascicule Neuroptéridées. 58 pp. Études des Gîtes Minéraux de la France, Paris.

BRZYSKI, B., DYBOVA-JACHOWICZ, S., KARCZEWSKA, J., KMIECIK, H., KoTASOWA, A., MigIER, T. \& SKOMPSKI, S. 2001. Budowa Geologiczna Polski. Atlas skamieniatości przewodnich i charakterystycznych. Młodszy paleozoik, Karbon, Flora, III (1c). 928 pp. Państwowy Instytut Geologiczny, Warszawa.

ClEAL, C.J. 2008. Westphalian-Stephanian macrofloras of the southern Pennines Basin, UK. Studia Geologica Polonica 128, $25-41$.

Cleal, C.J., JAmes, R.M. \& ZODROW, E.L. 1999. Variation in stomatal density in the late Carboniferous gymnosperm frond Neuropteris ovata. Palaios 14(2), 180-185. DOI $10.2307 / 3515373$

CleAL, C.J. \& ShUTe, C.H. 1992. Epidermal features of some Carboniferous neuropteroid fronds. Review of Palaeobotany and Palynology 71, 191-206. DOI $10.1016 / 0034-6667(92) 90162-A$

CLEAL, C.J. \& SHUTE, C.H. 1995. A synopsis of neuropteroid foliage from the Carboniferous and Lower Permian of Europe. Bulletin of the Natural History Museum 51(1), 1-52.

CLEAL, C.J. \& ZODROW, E.L. 1989. Epidermal structure of some medullosan Neuropteris foliage from the middle and upper Carboniferous of Canada and Germany. Palaeontology 32(4), 97-106.

Gothan, W. 1941. Paläobotanische Mitteilungen, 5-7. Paläontologische Zeitschrift 22, 424-438.

LAVEINE, J.-P. 1997. Synthetic analysis of the Neuropterids. Their interest for the decipherment of Carboniferous palaeogeography. Review of Palaeobotany and Palynology 95(1-4), 155-189. DOI 10.1016/S0034-6667(96)00033-4

LAVEIne, J.-P., Lemoigne, Y. \& ZHANG, S.Z. 1993. General characteristics and palaeobiogeography of the Parispermaceae (genera Paripteris Gothan and Linopteris Presl), Pteridosperms from the Carboniferous. Palaeontographica, Abteilung B 230(1-6), 81-139.

LAVeine, J.-P., Zhang, S., LiU, L., AN, D., Zheng, Q., CAO, J. \& LEMOIGNE, Y. 2003. The late Palaeozoic floras of the Hotan area (Xinjiang Uygur Autonomous Region, Northwest China), and their palaeogeographical significance. Revue de Paléobiologie 22(2), 473-559.

STERNBERG, K.H. VON 1821. Versuch einer geognostisch botanischen Darstellung der Flora der Vorwelt. Bd. I., Hft. 2. 33 pp., tent. I-XLII. F. Fleischer, Leipzig.

ŠIMŮNEK, Z. 2007. Cuticular analysis of medullosan pteridosperms from the Radnice Member (Pennsylvanian) of the Central and Western Bohemian basins (Czech Republic), 389-401. In WONG, T.E. (ed.) Proceedings of the $X V^{\text {th }}$ International Congress on Carboniferous and Permian Stratigraphy, Utrecht. Royal Dutch Academy of Arts and Sciences, Amsterdam.

S̆IMU゚NEK, Z. 2009. A large specimen and cuticles of Paripteris gigantea (Sternberg) Gothan from its type area Žacléř (Pennsylvanian, Czech Republic). Bulletin of Geosciences 84(2), 264-282.

WAGNER, R.H. 1984. Megafloral Zones of the Carboniferous. Compte Rendu Neuvičme Congrès International de Stratigraphie et de Géologie du Carbonifère, Washington and Champaign/Urbana 1979, 2, 109-134.

Zhang, S., Huo, F., CaO, J., Liu, Z., Laveine, J.P. \& LEMOIGne, Y. 1993. The Carboniferous flora of Zhongning district, Ninxia Region, North China. Revue de Paléobiologie $6,1-93$. 